\title{
Review
}

\section{Everyday utopias: The conceptual life of promising spaces}

\author{
Davina Cooper \\ Duke University Press, Durham, NC; London, 2014, 283 pp., \$24.95/\$89.95, \\ $£ 15.99 / £ 57.00$, ISBN: 978-0822355694
}

Contemporary Political Theory (2015) 14, e212-e215. doi:10.1057/cpt.2014.22;

published online 28 October 2014

This intriguing book investigates 'socially experimental practices' ranging from local exchange trading schemes (LETS) in the United Kingdom to an organized casual sex space for women in Toronto. Davina Cooper directs our attention to six such contemporary 'everyday utopias' - a term meant to capture the melding of the radical and the quotidian. She explains that the diverse projects she addresses share a simultaneously ambitious and pragmatic orientation, manifest in efforts to reshape aspects of day-to-day living in counter-hegemonic ways. The sites the book contemplates endeavor to do things otherwise, here and now. They do not, however, seek a totalizing ideal - as some understandings of 'utopia' would suggest - but instead direct their critical and visionary desire toward specific activities and toward what is 'doable and viable given the conditions of the present' (p. 4).

One of the most compelling features of the book is Cooper's insistence that minoritarian socio-political practices matter. They matter, she suggests, in at least three ways. 'Hot spots of innovative practice' (p. 9) like the ones Cooper analyzes are significant in part because their very existence challenges monolithic accounts of the present. She rightly notes how frequently social analyses mistake the dominant for the exhaustive. Taking seriously - even just noticing - collective attempts to forge new ways of being restores texture to a world that is often homogenized in the name of 'neoliberalism', 'capitalism', 'politics', 'mainstream culture' and other generalities. Second, Cooper insists that attending to everyday utopias is not only a matter of producing a more complex and therefore accurate understanding of the contemporary scene. She claims that these 'potent, innovative sites ... can revitalize progressive and radical politics' (p. 11). Everyday utopias, she says, have the 'power to affect what we can imagine' and therefore have a crucial role to play in 'a social justice politics of change' (p. 227).

Third, Cooper argues that everyday utopias can open up a new understanding of concepts. This is perhaps a more unexpected claim than those above. It is also more

(C) 2015 Macmillan Publishers Ltd. 1470-8914 Contemporary Political Theory Vol. 14, 2, e212-e215 www.palgrave-journals.com/cpt/ 
central to the book's purpose, as signaled by the subtitle. Chapter 2 proposes that everyday utopias can provide vital insight into the character of concepts, revealing that they are never simply ideational, but are also (re)produced by concrete practices. In conversation with other work in 'utopian studies', Cooper explains that everyday utopias - as 'minor-stream spaces' - 'generate concepts not simply through what participants think and believe but also through what they collectively do' (p. 25). As everyday utopias seek to bring into being 'other ways of living' in the present, they illuminate the interconnections between 'imagination and actualization'. Cooper argues that 'utopias are fundamentally different from campaigns, arguments or slogans that declare the change they wish to see', because they actually forge experimental ways of living in the present (p. 33). Such endeavors thus illuminate what is true of all concepts, according to Cooper, but usually neglected: the extent to which concepts are processes rather than things, entailing 'movement between imagining and actualization' (p. 36). This movement is not seamless or predictable, on Cooper's telling, however; concepts are dynamic and often marked by disjuncture or friction between what is imagined and what is actualized, a point she pursues in her case studies (p. 34). Cooper's primary claim concerning the 'conceptual life of promising spaces' is that they provide support for a 'materialist conceptual framework' that affirms the mutual imbrication of thinking and doing.

Chapters 3-8 each address a single 'everyday utopia' as Cooper aims to make good on the claim that such undertakings are both politically and theoretically significant. The six case studies that constitute the heart of Cooper's book are: 'equality governance' in Britain, circa 2009-2010 (Chapter 3); public nudity in contemporary Britain (Chapter 4); a women's and trans bathhouse in Toronto that has served as an organized casual sex space since 1998 (Chapter 5); LETS in Britain in the 1990s (Chapter 6); Summerhill School in England, a 90-year old residential private school dedicated to children's individual and collective self-government (Chapter 7); and Speaker's Corner in London's Hyde Park, a long-standing site for open public debate (Chapter 8). She acknowledges that it may seem strange to group these projects together, placing, for example, state-centered policies related to the Equality Act 2010 alongside more obviously resistant and marginal undertakings such as performances of public nudism. Yet Cooper maintains that these cases, however varied, are similarly ambitious in their effort to create a more desirable future (from the general perspective of 'progressive politics') and to attempt to do so by actively transforming a particular feature of social existence in the present.

The six projects she addresses are often fascinating. And Cooper draws on an impressive array of material, including her own interviews with participants as well as relevant primary documents, to construct her case studies. Unfortunately, the interpretations she offers of the six specific sites are often confusing and underdeveloped. Most troubling is Cooper's persistent tendency to select a particular 'unexpected' idea or framework at the start of a chapter, with very little justification, and proceed to 'read' an everyday utopia 'through' that lens (pp. 13, 45). The resulting 
analyses tend to feel somewhat arbitrary (why this lens rather than that one?) and are further compromised by an execution that obscures the stakes of the inquiry. For example, in the first sentence of the chapter that examines the 'equality governance agenda' under the Blair-led Labour government, Cooper announces, 'I use touch to explore equality as a state-led governance project' (p. 45). She refers to 'touch as a lens' stating, 'I explore what happens when we look at equality governance through touch' (p. 46). Yet there is little effort made to explain to readers why this is a worthwhile starting point. The bulk of the chapter is devoted to locating 'touch idioms' in about 30 official public texts produced by the Government Equalities Office and the Equality and Human Rights Commission. However, this analysis lacks weight as Cooper tends to point out words - 'embracing', 'barriers', 'treatment', 'balance' and so on - which she identifies as part of a 'haptic idiom' without offering a rigorous analysis of this discourse or its effects (pp. 53, 54). The discussion is additionally compromised by its reliance on a number of terms and associations that remain opaque, never clearly articulated or defended: 'public bodies', 'inner, constituting touch', 'a touched state' and the recurring conflation of physical touch with emotion.

In the book's introduction, Cooper states that rather than offering an 'insider's account' that would focus on the meaning of the six utopian sites for their participants, she provides 'one visitor's interpretation' of them. She also specifies that the book does not focus on those concepts that may seem to be most central to the projects themselves and instead considers the sites 'in relation to unexpected concepts - property, for instance, rather than freedom at Summerhill School' (p. 13). This approach certainly holds potential and could perhaps enable fresh insights. However, this potential remains mostly unrealized, for two major reasons. First, the interpretive decisions Cooper makes seem, even by the end of the book, almost random. The 'queer' pairings of an everyday utopia with an unconventional concept come across as esoteric intellectual exercises rather than fruitful political-theoretical analyses. The couplings of phenomena and concepts are as follows: equality governance and touch; public nudism and equality; queer casual sex space and feminist care ethics; LETS and normative time; Summerhill School and property; Speaker's Corner and the marketplace. Many of these frames seem to obscure rather than illuminate the everyday utopias the book aims to explore. How generative is it, really, to categorize Speaker's Corner as a marketplace when that choice has the effect of covering over one of the most striking features of that space - its noncommercial character? And what is gained by comparing the practices of a queer bathhouse with the tenets of feminist care ethics, given that those who created and sustained the space were not particularly interested in 'care', though they were oriented toward the - quite utopian - ends of affirming women's sexual agency, pursuing public eroticism and providing organized opportunities for new sexual skills to be acquired?

Cooper's decision to impose what she calls 'unexpected concepts' on these sociopolitical experiments is especially confounding given the fact that the book also advances a 'materialist conceptual framework'. That framework, laid out in Chapter 2 
and summarized above, is meant to recognize that concepts are not abstractions 'out there' but are generated in the movement between ideas and practices, both understood as embedded features of social life. Such a framework would seem to invite an encounter with everyday utopias that explores the interaction between key ideas and specific activities within the rich context of a specific 'promising space'. However, Cooper does not pursue this path. The approach she takes in the case studies instead seems to sever thinking from doing, imagination from actualization, by treating concepts as discrete tools to be picked up by a theorist and then brought to bear on worldly phenomena. By enacting a one-way relationship in which the theorist selects an idiosyncratic concept - seemingly from 'out there' - through which to interpret political activities, Cooper betrays her own important commitment to a form of critical inquiry that 'foregrounds material practice' (p. 32). Even more significantly, the method winds up seeming strangely disrespectful of the everyday utopias, since these complex, vital projects are immediately rendered objects of the writer's own preferred rubric, a rubric which admittedly has nothing to do with what participants understand themselves to be doing.

Everyday Utopias is noteworthy for its focus on 'experiments in living' that are too often neglected or dismissed by those who study politics. At its best moments, the book pushes readers to re-consider the utopian as a minor but real characteristic of our world today, evident in innovative practices that seek to enact - and not only imagine - other ways of being. Too often, however, the book's interpretive pattern cannot fulfill its own compelling promise: showing readers how even small-scale counter-hegemonic projects can revitalize progressive politics and transform our understanding of the relationship between thought and action. 